\title{
Reorienting the Business School Agenda: The Case for Relevance, Rigor, and Righteousness
}

\author{
Andreas Birnik \\ Jon Billsberry
}

\begin{abstract}
This article contributes to the current debate regarding management education and research. It frames the current business school critique as a paradox regarding the arguments for 'self-interest' versus 'altruism' as human motives. Based on this, a typology of management with four representative types labeled: unguided, altruistic, egoistic, and righteous is developed. It is proposed that the path to the future of management education and research might be found by relegitimizing the 'altruistic' spirit of the classics of the great Axial Age (900-200 BCE) and marrying those ideas with the self-interest ideal of mainstream management theories based on economics. By advocating this, a business school agenda that is simultaneously rigorous, relevant, and righteous is promoted.
\end{abstract}

KEY WORDS: altruism, business school agenda, management education, relevance versus rigor,

righteousness, self-interest

\section{Introduction}

Currently, there is great uncertainty about what management students should be taught and what they should learn (Bennis and O'Toole, 2005; Blood, 2006; Burke and Sadler-Smith, 2006; Cameron, 2006; Clegg and Ross-Smith, 2003; Ferraro et al., 2005; Julian and Ofori-Dankwa, 2006; Kanter, 2005; Mintzberg, 2004; Pfeffer, 2005; Pfeffer and Fong, 2002, 2004; Samuelson, 2006). These authors ask many fundamental questions about the nature of our work: Are there knowable certainties about the nature of work? Can the business world be reduced to scientific fundamentals? What is the role of managers? Is business about the pursuit of profit? Should managers be ethical? Is greed good? Recent financial scandals have fuelled this crisis in management education as a string of top executives, many of whom seem to have MBAs from the best schools, destroy organizations with their fraudulent misdeeds. At the present moment, Jeffrey Skilling (Harvard MBA) and Andrew Fastow (Northwestern MBA) are serving lengthy prison sentences from their criminal acts that led to the subsequent destruction of Enron.

The scientific model dominates the management education and research agenda (Bennis and O'Toole, 2005; Burke and Sadler-Smith, 2006; Clegg and Ross-Smith, 2003; Ghoshal, 2005; Mintzberg, 2004). This is an approach to business based on economic self-interest that is deep-rooted in the curricula of business schools. As a result, it is argued that business schools have become bastions of selfserving or egoistic management that fail to infuse students with a deeper sense of purpose or ethos compared with many other professions.

One consequence of the dominance of this model is that it has crowded out classic human insights that were developed during the great Axial Age (900-200 BCE); the term 'Axial Age' was coined by the German philosopher Karl Jaspers, and refers to the period in human history when most major religions were formed and philosophy flourished in ancient Greece (Armstrong, 2006; Jaspers, 1953). The Axial Age brought an increased focus on values such as altruism, belonging, compassion, and empathy to human civilization. Simultaneously, the 'Golden Rule' (explained later) emerged across different civilizations that had limited or no contact between them.

In light of the recent corporate scandals, there are grounds to argue that business schools should embrace the ideals of the Axial Age, which are still current in other disciplines. An example is the 
Hippocratic Oath, which pledges medical practitioners to the fundamental principle that they should 'never do harm to anyone' (Temkin and Temkin, 1968).

This article builds on the recent critique of management education and argues for the reorientation of the business school agenda toward 'righteous management,' which is based on the pluralistic promotion of self-interest and altruism rather than a focus on self-interest alone. It is argued that the popular mantra of 'relevance and rigor' should be expanded to 'relevance, rigor, and righteousness.'

The article begins with a review of the current debate on the problems confronting management education and research. This is followed by a review of the proposed solutions and the barriers to change. Based on this understanding, the current debate between self-interest and altruism is characterized as a paradox and different strategies for coping with paradoxes are explored. Emerging from this discussion is the notion of 'righteous management,' which is discussed as a possible way forward. The article concludes with a discussion of how these ideas might be implemented.

\section{The crisis in management education}

On the surface, management education appears to be prospering. Since the end of the Second World War, there has been a dramatic increase in the number of institutions offering undergraduate and graduate business programs. This strong growth in business education has become a global phenomenon, which has not been restricted to the United States. Judged against this background, one cannot deny that business schools represent a success story in the education industry. However, the future viability of the current business school paradigm has increasingly come under fire from a number of prominent scholars with long-standing business school careers.

Concerns that have been expressed include the overly scientific and analytical nature of management education, its domination by economics, a narrow focus on publishing, a lack of professionalism, an absence of practitioners, its inexperienced students, and its lack of relevance to the 'real world' of business.

Several authors (Bennis and O'Toole, 2005; Clegg and Ross-Smith, 2003; Ghoshal, 2005;
Mintzberg, 2004) have argued that business schools have all too eagerly embraced the scientific model in their desire to move away from the previous stigma of having been considered mere vocational trade schools rather than respectable academic departments, which is sometimes referred to as 'physics envy' (Clegg and Ross-Smith, 2003). As a result, mathematical elegance has driven the development of reductionist, prescriptive models of management (Ghoshal, 2005). The scientific model has also led to the loss of pluralism by crowding out other forms of scholarship not aimed at formal discovery (Bennis and O'Toole, 2005; Ghoshal, 2005). As a consequence of this, scholarly efforts aimed at teaching, practice, and integration have lost out in relative value (Boyer, 1990; Ghoshal, 2005). In this context, it is also worth noting that AACSB accreditation standards (AACSB, 2007a) emphasize three types of scholarship: discipline-based scholarship, contributions to practice, and learning and pedagogical scholarship. However, the relative weight and importance between these activities is often tilted strongly in favor of discipline-based scholarship when it comes to key decisions such as the granting of tenure in business schools.

The 'scientific model' has placed a clear emphasis on analysis in general, and quantification in particular, rather than on the development of essential managerial qualities such as judgment, interpretation, reflection, and personal values. Given this, it has been questioned if MBA programs really teach 'analysis' rather than administration or management (Bennis and O'Toole, 2005; Clegg and Ross-Smith, 2003; Mintzberg, 2004; Navarro, 2006; Pfeffer and Fong, 2002). It has also been argued that business school students learn to talk about business rather than to practice business (Pfeffer and Fong, 2002), and that students learn to analyze neatly packed cases superficially without developing any deep understanding of the contexts of the case organizations (Mintzberg, 2004).

Several scholars have argued that the dominance of economics as an underlying paradigm in business schools has a negative impact (Ferraro et al., 2005; Ghoshal, 2005; Pfeffer, 2005; Pfeffer and Fong, 2004). One consequence of this domination is evidence that economics-centric education, based on the underlying assumption of self-interest, makes students more egoistic and self-centered in their 
behavior (Pfeffer, 2005; Pfeffer and Fong, 2004). It has also been argued that much of economics is based on a pessimistic view of human nature aimed at containing human imperfections, representing an essentially negative theory of management (Ghoshal, 2005; Ghoshal et al., 1999; Ghoshal and Moran, 1996). Furthermore, economics-based theories like agency theory and transaction cost economics might become self-fulfilling and stimulate the opportunistic behaviors they seek to contain, leading to a vicious circle (Ferraro et al., 2005; Ghoshal, 2005; Ghoshal and Moran, 1996). Such economics-based theories also elevate the claims of shareholders above claims by other stakeholders of corporations (Ferraro et al., 2005; Ghoshal, 2005). Ghoshal (2005) has also argued that business schools' teachings might have contributed to widely publicized corporate scandals such as Enron and Tyco. In a similar vein, Mintzberg (2004) has stated that business schools tend to make students arrogant rather than humble.

Business schools have also been accused of putting too much emphasis on a narrow scholarly debate in increasingly specialist and esoteric management journals that are far removed from management practice (Bennis and O'Toole, 2005; Clegg and Ross-Smith, 2003). Tenure decisions by universities tend to institutionalize the current paradigm and academics who reject the dominant model do so at the risk of being denied tenure (Bennis and O'Toole, 2005). Pfeffer and Fong (2002) presented evidence that the narrow focus of academic research has resulted in low impact on practice of academic management research. In addition, they found that high impact publications in the management field were dominated by nonacademics.

It has also been argued that the management field lacks an ethos regarding the intrinsic value of pursuing management as a professional career in the same manner as medicine or the law (Pfeffer, 2005; Pfeffer and Fong, 2004). As a result, the value proposition of business schools is seen as too focused on extrinsic motives such as career advancement and getting a higher salary (Pfeffer and Fong, 2004), which attracts corporate 'mercenaries' primarily interested in monetary rewards rather than in the actual practice of management (Mintzberg, 2004).

Pfeffer and Fong (2002) and Bennis and O'Toole (2005) have argued that business schools have become too far removed from the profession they supposedly serve. A colorful quote illustrates this line of reasoning:

We cannot imagine a professor of surgery who has never seen a patient, or a piano teacher who doesn't play the instrument, and yet today's business schools are packed with intelligent, highly skilled faculty with little or no managerial experience. As a result, they can't identify the most important problems facing executives and don't know how to analyze the indirect and long-term implications of complex business decisions. In this way, they short change their students and, ultimately society (Bennis and O’Toole, 2005, p. 103).

The distance of faculty from the profession they serve is compounded by the inexperience of many management students. Mintzberg (2004) has argued that business school programs such as the MBA educate the wrong people as most are young with little or no managerial experience; the combination of these two factors risks cases of the "blind leading the blind.'

Finally, and influenced by the factors discussed above, management education and research are viewed by several scholars as suffering from a serious lack of relevance (Ashkanasy, 2006; Bennis and O'Toole, 2005; Pfeffer and Fong, 2002, 2004; Starkey and Madan, 2001). Pfeffer and Fong (2002) also found a lack of evidence that MBA programs actually furthered participant's careers. In addition, they found no relationship between high performance (measured as grades) and participant's future career success. It has also been argued that business schools add more value as selection mechanisms to sort our motivated and talented people rather than as learning institutions where participants develop their managerial skills (Pfeffer and Fong, 2004; Mintzberg, 2004).

\section{Solutions to the crisis}

Although the picture painted above may seem very bleak, there have been some counter arguments and suggested remedies. These include arguments for a return to university roots, a refocusing on experienced managers, reforms to the curriculum, a contextualization of teaching, new publication outlets, and the professionalization of management.

Pfeffer and Fong (2004) proposed that business schools should return to their classic university roots 
rather than act as business enterprises to satisfy the current market of students and other stakeholders. This would mean marketing the intrinsic value of business school education and a business career, and reduce the current focus on extrinsic motivations such as career advancement and financial enrichment. They consider professional schools in law and medicine as suitable role models.

One solution to the concern about the youthfulness or inexperience of management students is to focus management education on experienced midcareer managers, preferably while they are working in managerial roles (Mintzberg, 2004; Pfeffer and Fong, 2002). This would make possible the leverage of participants' own experience in the class room (Mintzberg, 2004) and the application of course components to participants' organizations (Pfeffer and Fong, 2002). This strategy would challenge the relevance of management educators and may raise concerns about their distance from commercial life.

Curriculum changes have been advocated (Bennis and O'Toole, 2005; Pfeffer, 2005). In particular, scholars suggest a move away from analytical, discipline-based teaching toward a greater focus on multidisciplinary, practical, and ethical questions. Such changes include a greater focus on course content from the humanities (Bennis and O'Toole, 2005) and centering management education on personal reflection (Mintzberg, 2004).

To mitigate the scientific focus in management education, several authors (Clegg and Ross-Smith, 2003; Flyvbjerg, 2001; 2006) have argued that management research and teaching should move away from the pursuit of universal, abstract rules, and instead, seek practical context-defined teaching and research. In a related manner, other authors, often labeled as 'Mode 2,' (e.g., Tranfield, 2002; Tranfield and Starkey, 1998; Van Aken, 2004) argue that a defining characteristic of management research should be its applied nature.

Pfeffer (2005) has suggested that changes are needed to the research outlets in the management field. He argues that the narrow, scholarly focus of the top management journals encourages single-issue empirical work, which frequently omit or limit a discussion of wider issues related to the research. Instead, he argues for revised outlets, in which debates about the public policy implications of management research ideas can be discussed.
Further, Pfeffer (2005) and Pfeffer and Fong (2004) contend that management needs to develop into a profession with a strong ethos in much the same manner as medical practitioners and lawyers. Pfeffer (2005) argues that management education needs to be concerned with the why and what of managerial action in addition to the how.

\section{Factors blocking change}

Despite many prominent academics that have entered the debate, there is widespread consensus that change will not be easy. The scientific paradigm of management education and research has become institutionalized, (Pfeffer and Fong, 2002), and a number of factors have been identified that make changing business school practice problematic.

At many business schools, the development of new faculty is shaped by the current tenure system. To get promoted, they must publish in the top academic journals and to do that, they must adhere to particular research traditions. This makes it very risky for young academics not to play according to the established rules as represented in these journals (Bennis and O'Toole, 2005; Ghoshal, 2005). Further, and as mentioned earlier, these journals are increasingly specialist and far removed from the world of management practice (Bennis and O'Toole, 2005; Clegg and Ross-Smith, 2003); they represent the pinnacle of research that senior faculty value and reward. Accordingly, the tenure system conditions young faculty and perpetuates the type of research that currently gets published.

The current system of business school and MBA rankings is also seen as contributing to maintaining the status quo (Julian and Ofori-Dankwa, 2006; Pfeffer and Fong, 2004). As a result, top schools have a low incentive to change (Pfeffer and Fong, 2002) and many new innovations originate from schools in lower tiers of the rankings with less to lose, but also correspondingly lower impact (Bennis and O'Toole, 2005).

Further, it has been argued that the current management education paradigm endures because it suits many stakeholders. The current business school value proposition suits many students who seek rapid career and salary advancement (Pfeffer and Fong, 2004). Kanter (2005) has argued that the common 
economic-man/shareholder value theories had a good fit with American managers advocating rather one-sided shareholder capitalism in the 1980s. This served to limit the popularity of alternative theories. Bennis and O'Toole (2005) have proposed that the current system suits many business school academics well given that they have grown up and positioned themselves within the system. Similarly, Pfeffer and Fong (2002) have argued that the detachment from managerial practice of most current faculty members means that they are simply not capable of providing a greater link with practice.

\section{A contribution to the debate}

Although the literature has dichotomized into 'a crisis and a solution' format to discuss the issues confronting business schools, it is important to emphasize that business schools can embrace intellectual pluralism taking lessons from both the scientific approach and a more humanitarian one. As discussed later, this debate need not be an 'either/or' one where the strengths of one of the approaches dominate the other. The core issue that needs to be addressed relates to the underlying assumptions and purpose of management rather than just structural reforms of the business school agenda or changing the composition of instructors and participants. Focusing on the underlying assumptions is a worthwhile effort despite many factors maintaining the status quo described above. However, structural reforms will ultimately prove to be unsuccessful if the more fundamental philosophical issue of the purpose of management is not addressed. Only once, there is agreement about the purpose of management, will it be possible to design the necessary structural reforms (cf. Bartlett and Ghoshal, 1989).

\section{The paradox of egoism (self-interest) versus altruism (unselfishness)}

As noted previously, the pursuit of self-interest is often elevated as the fundamental and only legitimate human motive in mainstream economics theory, and this has had a significant impact on management studies. Historically, altruism has been its alter ego. Reconciling the paradox between egoism and altruism may provide the solution to the crisis in management education. However, such an approach is open to criticism from proponents of the pure self-interest view, as noted by Sesardic:

The belief in the existence of genuine altruism is still widely regarded as an underdog theory. This is well reflected in the fact that the whole debate about egoism and altruism is frequently conceptualized as being about the so-called paradox of altruism. The obvious suggestion here is that cards are so heavily stacked against altruism that the easiest way to resolve the controversy would be to simply agree that altruism does not exist at all (1999, p. 457, italics in original).

There is, however, a growing body of evidence originating from anthropology, evolutionary biology, and psychology (Hauser, 2006; Sober and Wilson, 1998; Kahneman and Tversky, 1973) arguing against the notion of the 'economic man' and suggesting that rational self-interest does not appear to be the only driver of human behavior. Sober and Wilson (1998) noted "the influence that psychological egoism exerts far outreaches the evidence that has been mustered on its behalf" (1998, p. 2). The authors note that "an objective judge would have to conclude that egoism does not deserve its position of strength as the dominant theory in the intellectual pecking order, and never did... Apparently, the egoism hypothesis was able to rise without any genuine means of support" (1998, p. 295). Sen (1987) has similarly argued that "while assertions [of the self-interest] conviction are plentiful, factual findings are rare. Claims that the selfinterest theory 'will win' have typically been based on some special theorizing rather than on empirical verification" (1987, p. 18). In a similar vein, Sober and Wilson (1998) find that "the idea that human behavior is governed entirely by self-interest and that altruistic motives don't exist has never been supported either by a coherent theory or a crisp and decisive set of observations" (1998, p. 8). This does not imply a rejection of self-interest as a driver of human behavior, but as Sen states "the real issue is whether there is a plurality of motivations or whether self-interest alone drives human beings" (1987, p. 19, italics in original).

Likewise, a pluralistic view of human behavior does not favor naive altruistic acts in all circumstances. Axelrod's (1984) classic study of Prisoner's Dilemma illustrated how always turning the other cheek might result in being exploited by the other player. Therefore, a clear case for balance exists as 
illustrated by the success of the 'tit for tat' strategy of "being nice, retaliatory, forgiving, and clear" (Axelrod, 1984, p. 54). Sober and Wilson (1998) are skeptical of the conclusions reached by the game theorists. They noted "one symptom of the individualistic perspective prevalent among game theorists is their use of the word cooperation rather than altruism.... The word cooperation is used by evolutionary game theorists, presumably because it is easier to think of cooperation as a form of selfinterest. The behavior is the same but it is labeled differently" (1998, p. 84, italics in original).

From the perspective of the advocates of the pure self-interest view, it would appear that other human motives such as altruism, belonging, compassion, and empathy have no place in management unless they are instrumental means deployed in the pursuit of ultimate self-interest. As Sen argues "the selfinterest view of rationality involves inter alia a firm rejection of the "ethics-related' view of motivation" (1987, p. 15, italics in original). The focus on selfinterest is often related back to Adam Smith's (1776/ 2003) Wealth of Nations. However, Smith's (1756/ 1790/2006) earlier work on The Theory of Moral Sentiments is often conveniently forgotten as it presents a far more complex and pluralistic perspective on human motivations. Sen concluded "it is precisely the narrowing of the broad Smithian view of human beings in modern economics that can be seen as one of the major deficiencies of contemporary economic theory. This impoverishment is closely related to the distancing of economics from ethics" (1987, p. 28). Based on their comprehensive overview of the evidence for and against altruism, Sober and Wilson reach the conclusion that "altruism can be removed from the endangered species list in both biology and the social sciences" (1998, p. 337).

\section{Addressing the paradox}

Several scholars have argued for the exploration of paradox in management research (Bouchikhi, 1998; De Wit and Meyer, 2004; Eisenhardt, 2000; Lewis, 2000; Morgan, 1997; Poole and Van de Ven, 1989; Stroh and Miller, 1994). Paradox has been characterized as "the simultaneous existence of two inconsistent states" (Eisenhardt, 2000, p. 703) or as the simultaneous existence of "contradictory yet interrelated elements" (Lewis, 2000, p. 760). The clash between the drive for self-interest and the pursuit of unselfishness or altruism exhibits this tension. Solutions to this paradox can be explored with a paradox lens (De Wit and Meyer, 2004; Poole and Van de Ven, 1989).

De Wit and Meyer (2004) and Poole and Van den Ven (1989) argue that there are four principal means to address paradoxes:

Either/or. It is possible to approach the tension as a selection problem and make a choice between the alternatives. This would correspond to selecting either of the star positions in Figure 1. As explained earlier, mainstream economics has made a clear choice in favor of self-interest as opposed to the pursuit of 'non-rational' altruistic motives (Rocha and Ghoshal, 2006).

Trade-off. The situation can be managed through some form of trade-off exercise whereby a balance is struck between the opposing forces of self-interest and altruism. In Figure 1, this corresponds to selecting one of the diamonds.

Spatial or temporal separation. There can also be spatial separation, in which different organizational units or actors are concerned with satisfying different demands. For example, an organization can largely operate on the principles of self-interest, but then have a special department engaging in activities

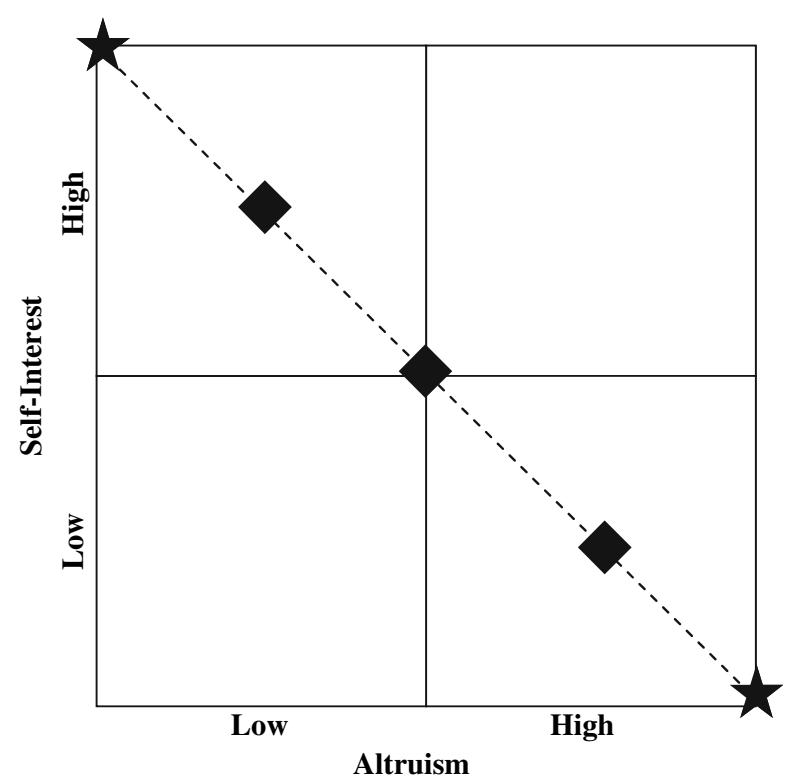

Figure 1. Incompatible opposites. 
aimed at altruistic motives perhaps labeled as "corporate social responsibility.' Similarly, the same organizational actors can attend to different demands at different times. This corresponds to what Brunsson (1985) has labeled organizational hypocrisy as a strategy of managing competing demands by decoupling talk, decisions, and actions.

Synthesis. This fourth strategy goes beyond accepting the factors in the paradox as being opposing, unidimensional, and mutually exclusive forces. The focus instead shifts toward exploring rather than suppressing tension (Lewis, 2000) with the objective of "getting the best of both worlds" (De Wit and Meyer, 2004, p. 16) or making both sides true (Stroh and Miller, 1994). Lewis (2000) has noted that paradoxes are socially constructed and that a transcendental mindset is required to break free from the accepted wisdom inherent in the paradox in order to move to a new conceptualization. This line of reasoning builds on dialectic logic, which seeks synthesis out of the thesis (self-interest) and antithesis (altruism).

Working with a premise that social reality is constructed rather than 'real' (Berger and Luckmann, 1966) makes it easier to break away from the theoretical shackles of the self-interest debate and to move toward the objective of seeking a resolution to the paradox through synthesis and reconceptualization. As argued by Morgan (1997), a way of seeing can become a way of not seeing. Based on the above, it is unsatisfactory to propose various forms of spatial or temporal separation, and trade-off exercises, to cope with the paradox as this would mean accepting the notion that self-interest and altruism always operate according to different and opposing logics of action (Friedland and Alford, 1991). A synthesis can be found through a strategy similar to that used by Rocha and Ghoshal (2006) who advocated self-love to move beyond the view of self-interest versus unselfishness. One concept that might provide synthesis between self-interest and altruism is righteousness, which provides mediation via its ethical roots.

\section{Righteousness}

The word righteous entered the English language in the 16th century as William Tyndale translated the Hebrew word 'tsedeq,' which appears over 500 times in the Old Testament. The etymology of the word means 'straightness' and 'tzedeq' is often translated as righteous, justice, equity, or ethically right (Strong, 1980). The Old Testament meaning of righteousness refers to the wider fulfillment of the demands of relationships rather than a more narrow legalistic interpretation of the term: A person is suspended in a multitude of different relationships, each bringing specific demands, and it is the fulfillment of these relationships that constitutes righteous behavior. Examples of such relationships include people with their God(s), ruler with subject, parents with children, community with the poor, and religious leaders with followers.

This Biblical definition is interesting because it places central importance on the need to fulfill a wide variety of relationships, while the proponents of the self-interest view advocate a strict focus on individual or organizational self-interest. The central importance placed on fulfilling the demands of relationships with others, is not in any way limited to the religious teachings of Judaism and Christianity as the subsequent discussion of the 'Golden Rule' will show. It is also worth noting that the Biblical definition of righteousness is clearly aligned with ideas in contemporary stakeholder analysis (e.g., Freeman and Reed, 1983). Hence, righteousness is herein defined broadly and not narrowly in line with religious writings that claim that only observers of one faith or another are righteous. This broad pluralistic definition accords with common development of reciprocity in many major religions. Citing work by Jaspers (1953), Armstrong (2006) argues that all major religions developed versions of the 'Golden Rule,' also referred to as the ethic of reciprocity (Religious Tolerance, 2006), during the Axial Age period of around 900-200 BCE. Hauser (2006) has similarly concluded "throughout history, and in all the world's cultures, various groups have articulated various versions of the Golden Rule" (2006, p. 357). In essence, the fundamental principle referred to as the 'Golden Rule' simply states 'we should treat other people as we wish to be treated ourselves.' Multiple versions exist of the Golden Rule as presented in Table I. Hauser noted "one interpretation of this sample is that when humans live in social groups, the Golden Rule emerges as an obligatory outcome, an explicit imposition that is handed down from on high" (2006, p. 358). From this, it would 


\section{TABLE I}

The Golden Rule (source: Religious Tolerance, 2006)

\begin{tabular}{|c|c|}
\hline Buddhism & $\begin{array}{l}\text { - 'Hurt not others in ways that you yourself would find hurtful.' } \\
\text { Udana-Varga 5:18 }\end{array}$ \\
\hline Christianity & $\begin{array}{l}\text { - 'And as ye would that men should do to you, do ye also to them likewise.' } \\
\text { Luke 6:31, King James Version. }\end{array}$ \\
\hline Confucianism & $\begin{array}{l}\text { - 'Do not do to others what you do not want them to do to you' } \\
\text { Analects } 15: 23\end{array}$ \\
\hline Hinduism & $\begin{array}{l}\text { - 'This is the sum of duty: do not do to others what would cause pain if done to you.' } \\
\text { Mahabharata 5:1517 }\end{array}$ \\
\hline Islam & $\begin{array}{l}\text { - 'None of you [truly] believes until he wishes for his brother what he wishes for himself.' } \\
\text { Number } 13 \text { of Imam 'Al-Nawawi's Forty Hadiths.' }\end{array}$ \\
\hline Jainism & $\begin{array}{l}\text { - 'A man should wander about treating all creatures as he himself would be treated.' } \\
\text { Sutrakritanga } 1.11 .33\end{array}$ \\
\hline Judaism & $\begin{array}{l}\text { - "What is hateful to you, do not to your fellow man. This is the law: all the rest is commenta } \\
\text { Talmud, Shabbat 31a. }\end{array}$ \\
\hline
\end{tabular}

appear that the 'Golden Rule' becomes a necessity to promote sustainability in society.

It is extraordinary that very different cultures, with no or limited contact between them (apart from the monotheistic troika of Judaism, Christianity, and Islam), all embraced the same idea, albeit expressed in slightly different ways. These religions all united in the pursuit of ideals of altruism, belonging, compassion, and empathy rather than around the continued rampant pursuit of the selfinterest ideal. The fact that the Golden Rule was expressed in widely diverse cultures makes the claim that it is a universal principle credible.

So the solution to the crisis in management education and research might be found by returning to the spirit of the Axial Age. ${ }^{1}$ The current critique regarding management education and research is characterized by a similar call for transformation of the business school community along the lines of the Axial Age transformation. If management scholars depart from the wisdom of the Axial Age, what is the underlying philosophy? How can management scholars adopt an ideology inspired by economics that is based on self-interest as the only worthwhile and rational motivator of human behavior?

\section{Toward a typology of management}

Based on the above discussion, a new conceptualization of management that explores the paradoxical tension between self-interest and altruism is proposed. This is represented graphically in Figure 2 below. In contrast to the linear trade-off line between selfinterest and altruism depicted in Figure 1, it rejects the idea that the factors are opposites on a single continuum. Instead, it depicts the emergence of a new option, which is labeled 'righteous management' based on fulfillment of a wider range of relationships than just shareholders or the selfinterest of management. The altruistic dimension is

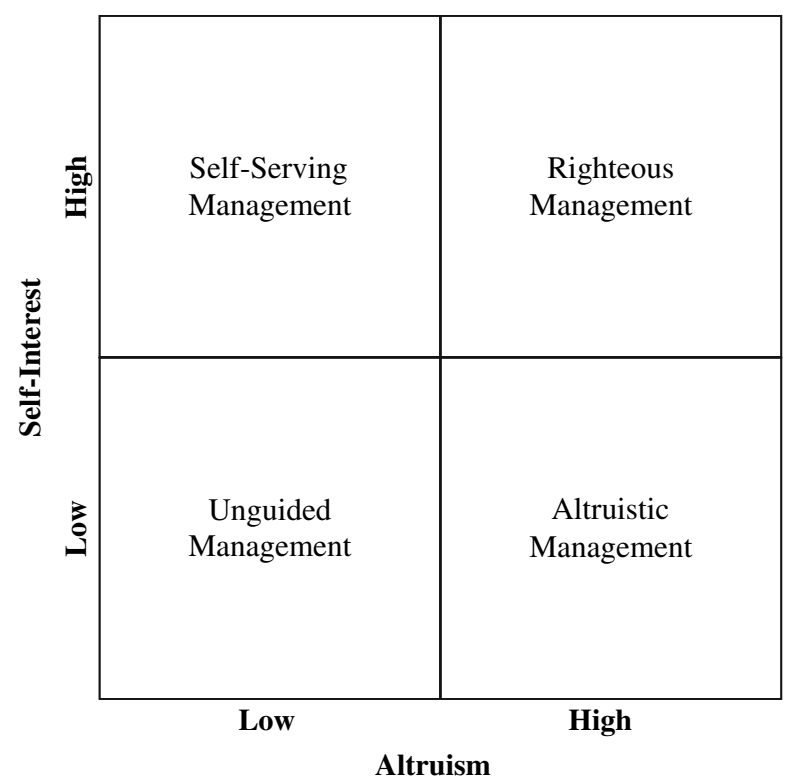

Figure 2. Different forms of management. 
distinguished from common forms of instrumental self-serving altruistic acts aimed at gaining legitimacy and securing resources (Brunsson, 1989; Pfeffer and Salancik, 1978). Such acts are driven by extrinsic motives rather than intrinsic desires. As a result, the organization pursuing such paths will constantly seek to minimize their supposedly altruistic acts or modify them to align better with perceived self-interests.

Unguided management. This quadrant is characterized by 'laissez faire' style management, which seeks to serve neither itself nor others. It is very unclear what the purpose of such management would be.

Altruistic management. This form of management genuinely seeks to serve others rather than the selfinterest of the organization or its members. As mentioned above, it should be distinguished from acts of self-serving altruism aimed at projecting a positive image, but ultimately conducted out of selfinterest. Altruistic management risks both ignoring growth and not tapping into the self-interest drive of its members. As such, it might alienate shareholders and professional managers.

Self-serving management. This form of management corresponds to the assumption of mainstream economics in its purist sense. The ultimate objective of management is to serve itself rather than others regardless of whether the results are positive, negative, or neutral. This quadrant also includes acts of self-serving altruism. Self-serving management risks creating the rampant pursuit of the self-interest of the organization, its managers, and shareholders. Negative consequences might include environmental degradation, poor treatment of employees, and its members might feel accountable to the organization, rather than other authorities.

Righteous management. In this quadrant, managers are concerned with integrating the seemingly opposing forces of self-interest and altruism. Righteous management rejects the idea that altruism and self-interest are noncompatible or that they need to be separated in time or space. Righteous management is based on intrinsic motives of personal excellence and self-love (Rocha and Ghoshal, 2006) aimed at improvement and doing good to oneself, the organization's members, and shareholders, as well as the greater community. It is characterized by a deep sense of service (Pfeffer and Fong, 2004). It genuinely aspires to live the often empty words of corporate vision statements. The metaphor of the
Olympic spirit captures the essence of righteous management. There are also clear parallels with what has been labeled 'organizational citizenship behaviors' including such behaviors as altruism, conscientiousness, civic virtue, sportsmanship, and courtesy (Organ and Ryan, 1995). However, as with any paradox, there are inherent tensions in the concept of righteous management and a corresponding risk of disagreement between organizational members who argue for the tilting of practices in the direction of either self-interest or altruism. Ironically, such tilting of management practice too far in either direction might result in righteous indignation from various stakeholders of the organization.

\section{Implications for the business school agenda}

The previous analysis suggests a need to advocate rigor, relevance, and righteousness as guiding principles. Above all, the time has come to reemphasize, and legitimize balance and pluralism in business schools. As demonstrated by the following quotes, numerous scholars highlight the limitations and dangers of embracing singular perspectives:

I favor a pluralistic position, one that recognizes different moral systems, and sees adherence to a singular system as oppressive (Hauser, 2006, p. 424).

We should construe altruism as part of a pluralistic theory of motivation that maintains that people have ultimate desires about others as well as about themselves. Egoism and hedonism, on the other hand, are rightly understood as (relatively) monistic doctrines (Sober and Wilson, 1998, p. 228, italics in original).

The world is increasingly seen, if only implicitly, as a federation of religions or civilizations, thereby ignoring all the other ways in which people see themselves. Underlying this line of thinking is the odd presumption that the people of the world can be uniquely categorized according to some singular and overarching system of partitioning... A solitarist approach can be a good way of misunderstanding nearly everyone in the world. In our normal lives, we see ourselves as members of a variety of groups - we belong to all of them (Sen, 2006, p. xii, italics in original).

In his book Scholarship Reconsidered, Ernst Boyer (1990) described four kinds of scholarship: the scholarship of discovery (research), the scholarship of integration 
(synthesis), the scholarship of practice (application), and the scholarship of teaching (pedagogy). Historically, business schools have celebrated and accommodated as equals the practitioners of all four kinds of scholarship. Over the last 30 years, we have lost this taste for pluralism (Ghoshal, 2005, p. 82, italics in original)

The value proposition for business school-based research rests on three important foundations: independence, rigor, and cross-fertilization. Collegiate business schools build and maintain an environment designed to support the pursuit of original ideas about business processes and organizations through scholarly inquiry. Through strict peer review, the academy seeks to protect the rigor of faculty research output. Furthermore, scholarly inquiry in business schools is enriched by collaboration among faculty representing a broad range of functional expertise within business and across a broad set of other areas ranging from mathematics to performing arts, political science to physics, and history to medicine (AACSB, 2007b, p. 8).

The quotes above, which are drawn from a wide variety of disciplines, all advocate the need for balance and pluralism. Hence, a case can be made for balance and pluralism as guiding forces of the business school agenda. This includes a number of potentially opposing drivers such as egoism versus altruism, rigor versus relevance, and top-tier versus impact publications. There are implications for teaching, publication, and the selection of faculty with the specific purpose of legitimizing a pluralistic business school agenda that is relevant, rigorous, and righteous.

The implications for teaching include the broadening of the business school agenda to include material from the humanities, sociology, and psychology, which rarely feature in economics, business, or statistics textbooks today. Instead, we advocate the inclusion of material from sources like literary classics, history, and biographies to provide historical comparisons and reference points. Such material should be studied in parallel to encourage an engagement with the central issues in the current debate. At present, this would include topics like environmental degradation, (absence of) free trade agreements, work-life balance, poverty reduction, security concerns, organized crime, and corruption. In addition, management students should be confronted with the consequences of their managerial actions. Films (e.g., Erin Brockovich, The Insider, Roger and Me, Ressources Humaines [Human Resources]), fieldwork, site visits (e.g., locales where factories have closed, victim-support centers, job centers), and cases highlighting ethical issues, such as the parable of the sadhu (McCoy, 1983), all offer this opportunity. The objective would be to get students to reflect critically and to develop their own value systems. There is also value in adopting shadowing schemes, such as those practiced in medical schools, to help students learn within a 'real' business environment where the actions of managers have important consequences. Some may mandate internships for faculty in both corporations and nonprofit organizations. Teaching should be used to stimulate reflexivity as an essential competence. This allows students to develop empathy and compassion in line with the Axial Age ideals. This call to action is consistent with Giacalone and Thompson (2006), who argue for the reorientation of the business school agenda away from an organization-centric worldview to a human-centered one. Boyer (1990) has also argued that collegiate life in the United States used to be oriented toward the development of students' character and the preparation of students to assume leadership positions in society. This principle objective of education was crowded out by the scientific model's pursuit for knowledge.

The implications for publication include the encouragement of faculty to engage with the central issues of our time where corporations have a major role to play. This means addressing policy to a much higher extent compared with today. It necessarily requires faculty to publish in mainstream outlets, rather than exclusively in academic journals, in order to influence current debates. Academics might be encouraged to reclaim some of the shelf space currently occupied by practitioner-oriented books produced by nonacademic writers. We also advocate following Pettigrew's (2007) suggestion that journal publication should be considered as an 'intermediate product.' The final product is in the form of real world impact. This necessitates a critical discussion relating to the criteria used to rank management research and, indirectly, business schools. Based on the objective of achieving 'real world impact,' it can no longer be sufficient simply to count publications in top tier academic journals as the measure of impact.

While 'relevance' is a worthwhile pursuit, it must be acknowledged that research implies navigating uncharted waters where the outcome is uncertain. 
As a consequence, management scholars may have to accept a high rate of failure in terms of less relevant research in order to increase the total output of relevant research. This might appear paradoxical, but is not unique to management research, but rather symptomatic of research and development efforts in general.

The implications for faculty selection include a focus on recruiting faculty that have the potential to become thought leaders in society and who aspire to become great educators. Given the search for a synthesis, it is clear that formal research will retain an important place in business schools. However, in order to play a more central role in society, faculty selection and promotion criteria also need to reward pluralism both in terms of assessing the backgrounds of candidates and assessing their contributions. A natural consequence of this suggestion is the idea that prior business experience should be considered more valuable compared with today. This might even include trying to find faculty members who are able to merge academic and organizational roles. Faculty remuneration systems will also have to be revised to take both practical and academic experience into consideration. There are cases where executives, with distinguished careers, have completed a doctorate only to be offered entry level academic salaries that completely discount the value of practical experience by a pure focus on the candidates' publication records. The same logic might apply to the appointment of senior university administrators. Seeking to attract prominent practitioners to administrative roles serves to safeguard that business schools do not become detached from the business community they supposedly serve. In this regard, the recent moves by some business schools, including INSEAD and London Business School to appoint practitioners as deans, appear apposite.

The implications for $M B A$ rankings are less clear. In the current climate with a vast multitude of competing business schools, MBA rankings are of critical importance to multiple stakeholders (e.g., Deans, university administrators, students, employers, alumni, funding bodies) for reasons of marketing, reputation, and profitability. All parties assess the performance of business schools through these measures and it would be naive to imagine that they will ever disappear. Although commentators have seen these rankings as contributing to the status quo as they discourage change in the top performing business schools, we see the rankings as a double-edged sword. We are heartened that schools that have recently made groundbreaking changes (such as the introduction of an issue-based curriculum at Yale) have been recognized in the rankings and this may, in turn, cause some of the highest ranking business schools to examine their own offerings. If we are right and the incorporation of ideas from the Axial Age has advantages for teaching and research, we would expect this to be recognized in the rankings.

What should the unique competence of business schools be? Should they focus on basic research and leave it up to our students to determine what to use? In this regard, it is interesting to note that James March opens his classes at Stanford with the statement "I am not now, nor have I ever been, relevant" (Coutu, 2006, p. 84) to signal to students that the beauty of ideas is more significant than their immediate relevance to the world of practice. Or should business schools be demolished in favor of a liberal arts curriculum focused on the humanities? The argument in this article is that business schools should be characterized by their applied nature. Business schools should relate to both the humanities and to economics in the same fashion that engineering relates to physics and medicine to biology. Given this, business schools should draw upon the humanities and economics, but should distinguish themselves through their applied focus on the practice-oriented world of management. From this perspective, a core competence of business school faculty would be to select relevant research produced by academics in basic disciplines and to develop applications of basic research. As a result, rather than a dominant focus on 'scientific' economics-based theories, business school faculty need to integrate material from the humanities to develop the human-centered worldview, as discussed above, with the objective of developing and legitimizing empathy and compassion. A management agenda dominated exclusively by managerial self-interest and the pursuit of profit will gradually lead to an impoverished and dehumanized view of management. Given this, it is important to legitimize the value of pluralistic objectives for businesses including providing good customer service, producing high quality product and services, having good employee relations, and achieving profitability. 
With an applied focus, it becomes critical for business schools to get closer to practice. Compare the typically lecture-based teaching in business schools with the way that medical doctors are being formed. Medical students learn anatomy by practicing on corpses, and then spend more than a year shadowing the real work of qualified doctors in hospital wards. In contrast, most full-time management students do not spend any time in 'real' organizations during their study period with the possible exception of shorter analytically-oriented consulting assignments. Such business school students get presented with instruction material that has been carefully manicured and prepared for them in convenient bite-size chunks. However, some innovative European full-time masters programs, including at the University of Luxembourg and at the Stockholm School of Economics integrate ongoing practice as part of their studies. In Luxembourg, each student follows a local company for the entire duration of their studies. In Stockholm, MBA students engage with longer 'live cases' throughout their studies. Both of these innovative curriculum changes serve the purpose of having students to engage with the messiness and ambiguity of management practice. In addition, we believe that practice can more easily be incorporated in part-time programs where students still remain in their jobs. We think it is unfortunate that many business schools provide identical courses across their full-time and part-time programs. Presumably, there should be substantial opportunities to leverage participants' ongoing practice in part-time programs and transcend the detachment from practice, which often characterizes full-time programs.

\section{Concluding remarks}

Promoting a business school agenda based on relevance, rigor, and righteousness will not be an easy path to walk. But the same is true for other central paradoxes in management such as balancing integration and responsiveness in multinational corporations (Bartlett, 1986; Bartlett and Ghoshal, 1989; Prahalad and Doz, 1987), exploitation and exploration in innovation and learning (Birkinshaw and Gibson, 2004; Gibson and Birkinshaw, 2004; March, 1991; O'Reilly and Tushman, 2004), environmental determinism versus strategic choice (Astley and
Van de Ven, 1983; Child, 1972; Hannan and Freeman, 1977; Hrebiniak and Joyce, 1985), or the focus on external market positions versus internal resources and capabilities (Barney, 1991; Eisenhardt and Martin, 2000; Penrose, 1959; Porter, 1980; Porter, 1985; Teece et al., 1997; Wernerfelt, 1984). Doing the 'right thing' is rarely easy, given the way that many societies have inculcated achievement, advancement, and the promotion of the self into their members. Even in the rarified climes of the Olympics, where an ethical approach is paramount, athletes push and transgress the ethical limits. Management educators and researchers must confront these challenges, or else business schools are doomed to a future where faculty's isolation and students' self-interest gets ever worse.

In an age obsessed with the academic pursuit of rigor and an increasing interest in relevance, the time has come to revert back to the classics of the Axial Age and reintroduce the notion of righteousness as a legitimate and worthwhile motive for human behavior. Management scholars need to become much more careful regarding the implicit ideological assumptions in their theories. By advocating this, the goal is to promote a business school agenda that is simultaneously rigorous, relevant, and righteous.

\section{Acknowledgments}

The authors would like to thank Ben Arbaugh, Neal Ashkanasy, Anita Beal, Mats Lingblad, Hsiao Rueylin, Siri Terjesen, Scott Valentine, Charles Wankel, and two anonymous reviewers for insightful and helpful comments on earlier drafts of this manuscript. All remaining faults are solely the responsibility of the authors.

\section{Note}

1 It is of course important that the promulgation of the enlightened spirit of the Axial Age is sought rather than a replication of negative tendencies such as misogynous practices and slavery.

\section{References}

AACSB: 2007a, Eligibility Procedures and Accreditation Standards for Business Accreditation (AACSB, Tampa, Florida). 
AACSB: 2007b, Report of the AACSB International Impact of Research Task Force (AACSB, Tampa, Florida).

Armstrong, K.: 2006, The Great Transformation (Atlantic Books, London).

Ashkanasy, N. M.: 2006, 'Arguments for a More Grounded Approach to Management Education', Academy of Management Learning and Education 5(2), 207-208.

Astley, W. G. and A. H. Van de Ven: 1983, 'Central Perspectives and Debates in Organization Theory', Administrative Science Quarterly 28(2), 245-273.

Axelrod, R.: 1984, The Evolution of Cooperation (Basic Books, New York).

Barney, J.: 1991, 'Firm Resources and Sustained Competitive Advantage', Journal of Management 17(1), 99-120.

Bartlett, C. A.: 1986, 'Building and Managing the Transnational: The New Organizational Challenge', in M. E. Porter (ed.), Competition in Global Industries (Harvard Business School Press, Boston).

Bartlett, C. A. and S. Ghoshal: 1989, Managing Across Borders: The Transnational Solution (Harvard Business School Press, Boston).

Bennis, W. G. and J. O’Toole: 2005, 'How Business Schools Lost their Way', Harvard Business Review 83(5), 96-104.

Berger, P. L. and T. Luckmann: 1966, The Social Construction of Reality (Doubleday, New York, Garden City).

Birkinshaw, J. and C. Gibson: 2004, 'Building Ambidexterity into an Organization', Sloan Management Review 45(4), 47-55.

Blood, M. R.: 2006, 'Only You can Create Actionable Knowledge', Academy of Management Learning \& Education 5(2), 209-212.

Bouchikhi, H.: 1998, 'Living With and Building on Complexity: A Constructivist Perspective on Organizations', Organization 5(2), 217-232.

Boyer, E. L.: 1990, Scholarship Reconsidered (The Carnegie Foundation for the Advancement of Teaching, Princeton, New Jersey).

Brunsson, N.: 1985, The Irrational Organization (Fagbokforlaget, Bergen).

Brunsson, N.: 1989, The Organization of Hypocrisy: Talk, Decisions and Actions in Organizations (John Wiley \& Sons, Chichester).

Burke, L. A. and E. Sadler-Smith: 2006, 'Instructor Intuition in the Educational Setting', Academy of Management Learning \& Education 5(2), 169-181.

Cameron, K.: 2006, 'Good or Not Bad: Standards and Ethics in Managing Change', Academy of Management Learning \& Education 5(3), 317-323.

Child, J.: 1972, 'Organization Structure, Environment and Performance: The Role of Strategic Choice', Sociology 6(1), 1-22.
Clegg, S. R. and A. Ross-Smith: 2003, 'Revising the Boundaries: Management Education and Learning in a Postpositivist World', Academy of Management Learning \& Education 2(1), 85-98.

Coutu, D.: 2006, 'Ideas as Art', Harvard Business Review 84(10), 82-89.

De Wit, B. and R. Meyer: 2004, Strategy: Process, Content, Context, 3rd Edition (Thomson Learning, London).

Eisenhardt, K. M.: 2000, 'Paradox, Spirals, Ambivalence: The New Language of Change and Pluralism', Academy of Management Review 25(4), 703-705.

Eisenhardt, K. M. and J. A. Martin: 2000, 'Dynamic Capabilities: What are They?', Strategic Management Journal 21, 1105-1121.

Ferraro, F., J. Pfeffer and R. I. Sutton: 2005, 'Economic Language and Assumptions: How Theories can Become Self-Fulfilling', Academy of Management Review 30(1), 8-24.

Flyvbjerg, B.: 2001, Making Social Science Matter: Why Social Inquiry Fails and How it Can Succeed Again (Cambridge University Press, Cambridge).

Flyvbjerg, B.: 2006, 'Making Organization Research Matter: Power, Values and Phronesis', in S. R. Clegg, C. Hardy, T. B. Lawrence and W. R. Nord (eds.), The Sage Handbook of Organization Studies, 2nd Edition (Sage, Thousand Oaks, California), pp. 370-387.

Freeman, R. E. and D. L. Reed: 1983, 'Stockholders and Stakeholders: A New Perspective on Corporate Governance', California Management Review 25(3), 88-106.

Friedland, R. and R. R. Alford: 1991, 'Bringing Society Back Symbols, Practices, Institutional Contradictions', in W. W. Powell and P. J. DiMaggio (eds.), The New Institutionalism in Organizational Analysis (Chicago, University of Chicago Press).

Ghoshal, S.: 2005, 'Bad Management Theories are Destroying Good Management Practices', Academy of Management Learning \& Education 4, 75-91.

Ghoshal, S., C. A. Bartlett and P. Moran: 1999, 'A New Manifesto for Management', Sloan Management Review 40(3), 9-20.

Ghoshal, S. and P. Moran: 1996, 'Bad for Practice: A Critique of the Transaction Cost Theory', Academy of Management Review 21(1), 13-47.

Giacalone, R. and K. Thompson: 2006, 'Business Ethics and Social Responsibility Education: Shifting the Worldview', Academy of Management Learning and Education 5(3), 266-277.

Gibson, C. B. and J. Birkinshaw: 2004, 'The Antecedents, Consequences, and Mediating Role of Organizational Ambidexterity', Academy of Management Journal 47(2), 209-226.

Hannan, M. T. and J. Freeman: 1977, 'The Population Ecology of Organizations', American Journal of Sociology 82(5), 929-964. 
Hauser, M.: 2006, Moral Minds: How Nature Designed our Universal Sense of Right and Wrong (HarperCollins, New York).

Hrebiniak, L. G. and W. F. Joyce: 1985, 'Organizational Adaptation: Strategic Choice and Environmental Determinism', Administrative Science Quarterly 30, 336-349.

Jaspers, K.: 1953, The Origin and Goal of History (Routledge, London).

Julian, S. D. and J. C. Ofori-Dankwa: 2006, 'Is Accreditation Good for the Strategic Decision Making of Traditional Business Schools?', Academy of Management Learning E Education 5(2), 225-233.

Kahneman, D. and A. Tversky: 1973, 'On the Psychology of Prediction', Psychological Review 80(4), 237-251.

Kanter, R. M.: 2005, 'What Theories do Audiences Want? Exploring the Demand Side', Academy of Management Learning E Education 4(1), 93-95.

Lewis, M. W.: 2000, 'Exploring Paradox: Toward a More Comprehensive Guide', Academy of Management Review 25(4), 760-776.

March, J. G.: 1991, 'Exploration and Exploitation in Organizational Learning', Organization Science 2(1), 71-87.

McCoy, B.: 1983, 'The Parable of the Sadhu', Harvard Business Review 61(5), 103-108.

Mintzberg, H.: 2004, Managers, Not MBAs (Pearson Education Limited, Harlow).

Morgan, G.: 1997, Images of Organization, 2nd Edition (Sage, Thousand Oaks, CA).

Navarro, P.: 2006, 'The Hidden Potential of "Managerial Macroeconomics" for CEO Decision Making in MBA Programs', Academy of Management Learning \& Education 5(2), 213-224.

O'Reilly, C. A. and M. L. Tushman: 2004, 'The Ambidextrous Organization', Harvard Business Review 82(4), 74-81.

Organ, D. W. and K. Ryan: 1995, 'A Meta-Analytical Review of Attitudinal and Dispositional Predictors of Organizational Citizenship Behaviors', Personnel Psychology 48(4), 775-802.

Penrose, E.: 1959, The Theory of the Growth of the Firm (Oxford University Press, Oxford).

Pettigrew, A.: 2007, Symposium at the Annual Meeting of the Academy of Management (Philadelphia).

Pfeffer, J.: 2005, 'Why Do Bad Management Theories Persist? A Comment on Ghoshal', Academy of Management Learning \& Education 4(1), 96-100.

Pfeffer, J. and C. T. Fong: 2002, 'The End of Business Schools? Less Success than Meets the Eye', Academy of Management Learning \& Education 1(1), 78-95.
Pfeffer, J. and C. T. Fong: 2004, 'The Business School 'Business': Some Lessons from the US Experience', Journal of Management Studies 41(8), 1501-1520.

Pfeffer, J. and G. R. Salancik: 1978, The External Control of Organizations (Harper \& Row, New York).

Poole, M. S. and A. H. Van de Ven: 1989, 'Using Paradox to Build Management and Organization Theories', Academy of Management Review 14(4), 562578.

Porter, M. E.: 1980, Competitive Strategy: Techniques for Analyzing Industries and Competitors (The Free Press, New York).

Porter, M. E.: 1985, Competitive Advantage (The Free Press, New York).

Prahalad, C. K. and Y. L. Doz: 1987, The Multinational Mission (The Free Press, New York).

Religious Tolerance: 2006, Versions of the Golden Rule in 21 World Religions, B. A. Robinson, Viewed 3 November 2006, http://www.religioustolerance.org/ reciproc.htm.

Rocha, H. O. and S. Ghoshal: 2006, 'Beyond SelfInterest Revisited', Journal of Management Studies 43(3), 585-619.

Samuelson, J.: 2006, 'The New Rigor: Beyond the Right Answer', Academy of Management Learning $\mathcal{E}$ Education 5(3), 356-365.

Sen, A.: 1987, On Ethics and Economics (Blackwell Publishing, Malden, MA).

Sen, A.: 2006, Identity and Violence (Norton, New York).

Sesardic, N.: 1997, 'Altruism', British Journal for the Philosophy of Science 50(3), 457-466.

Smith, A.: 1759/1790/2006, The Theory of Moral Sentiments (Dover Publications, Mineola, NY).

Smith, A.: 1776/2003, The Wealth of Nations (Bantam Dell, New York).

Sober, E. and D. S. Wilson: 1998, Unto Others: The Evolution and Psychology of Unselfish Behavior (Harvard University Press, Cambridge, MA).

Starkey, K. and P. Madan: 2001, 'Bridging the Relevance Gap: Aligning Stakeholders in the Future of Management Research', British Journal of Management 12, S3-S26.

Stroh, P. and W. W. Miller: 1994, 'Learning to Thrive on Paradox', Training \& Development, 28-39.

Strong, J.: 1980, Strong's Concordance of the Bible, IV Vols (Pickering \& Inglis, London).

Teece, D. J., G. Pisano and A. Shuen: 1997, 'Dynamic Capabilities and Strategic Management', Strategic Management Journal 18(7), 509-533. 
Temkin, O. and C. Temkin: 1968, Ancient Medicine: Selected Papers of Ludwig Edelstein (The John Hopkins Press, Baltimore).

Tranfield, D.: 2002, 'Formulating the Nature of Management Research', European Management Journal 20(4), 378-382.

Tranfield, D. and K. Starkey: 1998, 'The Nature, Social Organization and Promotion of Management Research: Towards Policy', British Journal of Management 9, 341-353.

Van Aken, J. E.: 2004, 'Management Research Based on the Paradigm of the Design Sciences: The Quest for Field-Tested and Grounded Technological Rules', Journal of Management Studies 41(2), 219-246.

Wernerfelt, B.: 1984, 'A Resource-Based View of the Firm', Strategic Management Journal 5(2), 171-180.
Andreas Birnik

Department of Business Policy,

NUS Business School,

National University of Singapore,

1 Business Link 117592, Singapore

E-mail:andreas@nus.edu.sg

Jon Billsberry

Open University Business School,

The Open University, Michael Young Building, Walton Hall, Milton Keynes, Buckinghamshire, UK E-mail:j.billsberry@open.ac.uk 